\title{
Psychological Tools Affecting Increasing Motivation to Learn Two Foreign Languages
}

\author{
Anatolii Furman 1,*, Anastasiia Bessarab ${ }^{2}$, Iryna Leshchenko ${ }^{3}$, Anastasiia Turubarova ${ }^{2}$, Andriy Hirnyak $^{4} \& \mathrm{Olha}$ \\ Furman $^{5}$ \\ ${ }^{1}$ Department of Theory and Methods of Practical Psychology, State Institution "South Ukrainian National Pedagogical \\ University named after K. D. Ushinsky", Odesa, Ukraine \\ ${ }^{2}$ Department of Special Education and Psychology, Municipal Institution of Higher Education «Khortytsia National \\ Educational Rehabilitation Academy» of Zaporizhzhia Regional Council, Zaporizhzhia, Ukraine \\ ${ }^{3}$ Department of Pedagogy and Psychology, Bohdan Khmelnytsky Cherkasy National University, Cherkasy, Ukraine \\ ${ }^{4}$ Department of Psychology and Social Work, West Ukrainian National University, Ternopil, Ukraine \\ ${ }^{5}$ Department of Social Sciences and Humanities, Municipal Institution of Higher Education «Khortytsia National \\ Educational Rehabilitation Academy» of Zaporizhzhia Regional Council, Zaporizhzhia, Ukraine
}

*Correspondence: Department of Theory and Methods of Practical Psychology, State Institution "South Ukrainian National Pedagogical University named after K. D. Ushinsky", 2, Staroportofrankivska Str., 65000, Odesa, Ukraine

Received: December 9, 2021

Accepted: January 6, 2022 Online Published: January 17, 2022

doi:10.5430/jct.v11n1p255

URL: https://doi.org/10.5430/jct.v11n1p255

\begin{abstract}
The problem of the formation and development of motivation to learn occupies one of the central places in educational institutions. Its relevance is due to the priority areas of development and modernization of education. In the article, the authors analyzed the motivation for learning a foreign language, the factors that affect it. Analysis of the literature revealed two main factors that can increase students' motivation to learn a second foreign language. The authors examined the maximum effectiveness of increasing student motivation to learn a second foreign language as a synergy of three components: the teacher's personality, which can create a safe motivating environment, focusing on other people's culture and the connection between two foreign languages. The authors proposed psychological and methodological tools to increase the motivation of students to learn two foreign languages. A distinctive feature is the synergy of 3 components (personality of the teacher, safe motivating environment and connection between two foreign languages). This toolkit was tested in 2 stages during 2019-2021 and showed its effectiveness.
\end{abstract}

Keywords: culture, connection, motivating environment, teacher's personality, safe environment

\section{Introduction}

The problem of the formation and development of motivation for learning occupies one of the central places in educational institutions. Its relevance is due to the priority areas of growth and modernization of education. The motives of teaching modern youth studying in educational institutions are undergoing significant changes under the influence of the new conditions of society, the new system of values that is promoted through various information channels. Therefore, the formation of motivation is not a simple increase in a positive or negative attitude towards learning, but the complication of the structure of the motivational sphere behind it, the motivations included in it, the establishment of new, more mature, sometimes contradictory relationships between them (Bashynska et al., 2021; Isroilova, 2021; Urban, 2021). These separate aspects of the motivational sphere should become the object of the teacher's control. Teachers cannot always clearly state why a student does not want to learn, what aspects of motivation he has not formed, in which case he does not want to learn, and in which case the teachers did not teach him to organize actions in such a way that motivation for learning appears.

Practical knowledge of a foreign language is an indisputable advantage of any specialist (Tkachenko et al., 2021; Turski et al., 2021). However, students do not consider it necessary to study, believing that they will not need a foreign language in their professional activities (Muradov et al., 2020; Riyanti, 2020; Telyani et al., 2021). 
Many scientists have studied various aspects of student motivation, but the motivation to learn two foreign languages at once is even the most challenging task. This question is relevant in the field of a changing world and new requirements for the future workforce. The purpose of the article is to find tools that can increase motivation to learn two foreign languages. The research assumes the fulfilment of the following tasks:

- study of the problem field of the subject of research through the analysis of relevant literary sources;

- highlighting the factors that have the most significant impact on motivation;

- development and testing of a methodology that increases motivation to learn two foreign languages.

\section{Literature Review}

At present, despite the multifaceted studies of the motivational side of learning carried out by teachers and psychologists, it remains the least controllable; however, as Merlin (1971) writes, "to control a person's actions ... is possible only through the control of motives".

Many scientists have studied motivation in its various manifestations:

- as a teacher's tool (Garn \& Simonton, 2022; Poplavskyi et al., 2020);

- as a set of qualities of students (Selivanova et al., 2018);

- modern tools (using IT technologies) to increase motivation through interest (Prokopenko et al., 2018; Berehil, 2022);

- non-standard creative ways to increase motivation (Vasiutiak et al., 2021; Rethinasamy et al., 2021);

- increasing motivation using psychological tools (Kozlovska et al., 2021).

According to psychological studies of motivation (Kozlovska et al., 2021; Garn \& Simonton, 2022), when teaching a foreign language, the efforts of teachers (external) should be directed to the development of students' motivation, which comes from the activity itself and has the tremendous incentive force. Without students' motivation, the teacher is unable to encourage students to learn the language.

In teaching foreign languages in a non-linguistic university, the following components should interact:

- the student and how he masters foreign language knowledge, skills and abilities: what motives encourage him to work;

- the teacher and how he teaches, guided by methodological principles, using methods, techniques, means and forms of training;

- the subject itself "foreign language" - that is, linguistic and speech units that must be entered into the memory of students, and, therefore, the content features for educational motivation should be determined by the following factors:

- the educational system,

- an educational institution,

- organization of the educational process,

- the specifics of the subject,

- subjective characteristics of the teacher (Pozdniakova, 2018; Pavlyuk, 2019; Burhonova, 2021; Isaeva et al., 2021).

For a teacher to successfully increase motivation, it is necessary to remember that the theory of needs is closely related to motivation. Maslow (1943) divides all needs into five primary levels:

at the first level are - physiological,

on the second - the need for security,

on the third - the need for love and affection,

on the fourth - the need for respect,

on the fifth - the need for self-actualization.

Kegan analyzed Maslow's theory; he identified six stages of student development: incorporative, impulsive, imperial, interpersonal, institutional, and interindividual (Kegan, 1982). Interestingly, in three of these stages, the teacher plays an essential role, a teacher plays an indispensable role: incorporative (null, imperial, and interpersonal. According to 
Kegan's theory, individuals operate at the level of sensorimotor reflexes at the incorporative stage. Therefore, it is unlikely that students will not stay at this stage for a long time. But it is at this stage, the teacher's personality should become a decisive factor in external motivation (Figure 1).

Personal characteristics of the teacher, his methodological literacy, orientation in the speciality that students receive, the teacher's awareness of the goals that students set for themselves, communication skills, openness, empathy, creativity in organizing the educational process, the emotional richness of classes, the system in the presentation of material, the system control and even appearance create the prerequisites for increasing motivation to learn a language. In addition, at this stage, acquaintance with students takes place. This is more than just memorizing their names. Students need to know that their teacher is interested in them and cares about them and their success. When students feel valued, it creates a safe learning environment and motivates them to work as they want to receive praise and support from someone they believe knows and respects them as individuals.

At the second stage of needs, which is called imperial, students are motivated by the results of their activity and the teacher's assessment. At this stage, the teacher needs to support the students. Every student, both advanced and early-stage students, should receive an evaluation of their performance. This grade should not be just a number; it is a detailed list of how much the student has progressed concerning his initial level since the beginning of his work on the language at the university. Students with an excellent background often earn much less than those who started learning a language from scratch. The teacher must find such techniques so that the strong do not lose interest, and the beginners can get satisfaction from their work.

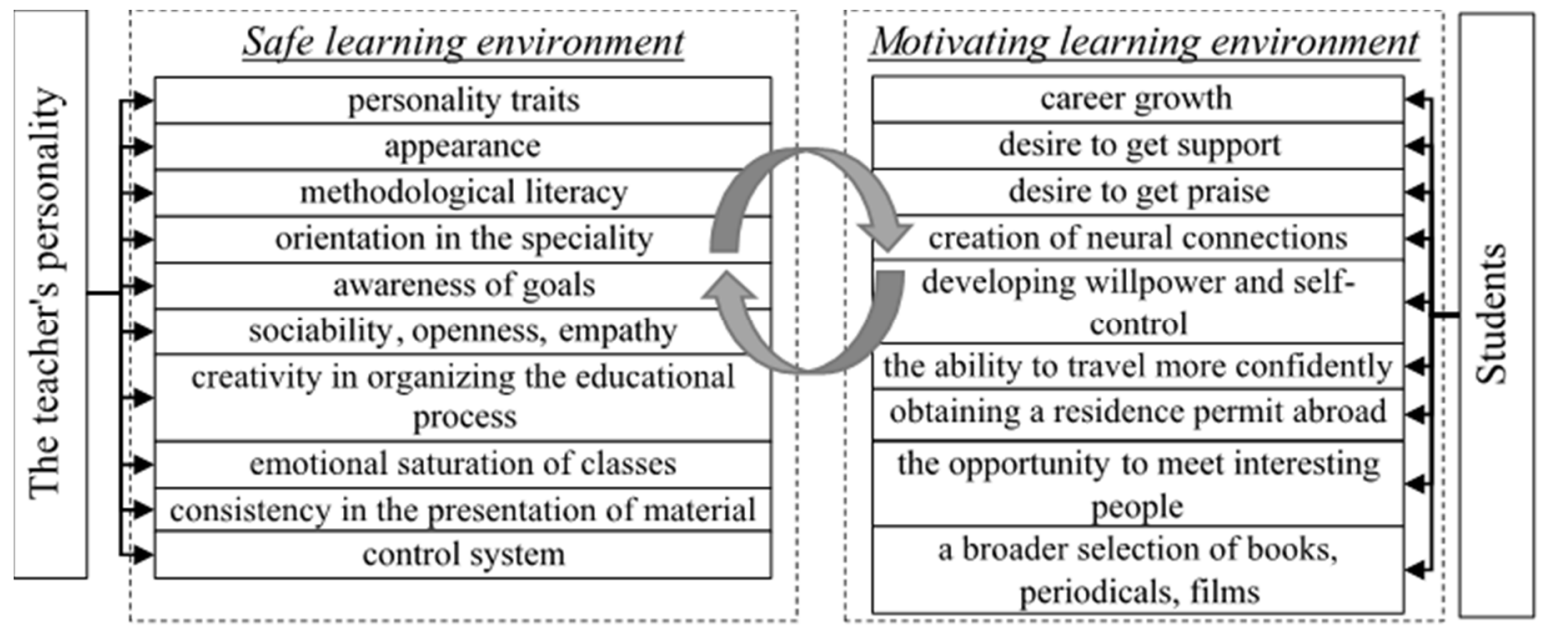

Figure 1. The Role of the Teacher's Personality in Motivating Students

Source: built by the authors based on (Kegan, 1982; Kozlovska et al., 2021; Telyani et al., 2021)

At the third - interpersonal - stage, students are motivated by the desire to increase their authority among fellow members, and they also feel the need for recognition. The teacher at this stage can help to strengthen the management and increase the student's self-esteem. One encouragement to a novice student can increase motivation for an extended period, but this is provided that the teacher's personality means something to him if the student respects him and tries to imitate him. In the hands of a competent teacher, censure can be a tool to increase motivation. There are quite a few students who are very jealous of the positions they have won. In this case, personal motives come to the fore: assessment reasons, success (when students perform work for the sake of assessment, praise), self-affirmation, and well-being. The pleasure that a person receives from a positive evaluation of his actions is the most substantial stimulus for internally motivated activity. Knowing well the characteristics of the needs of students and having determined at what level the student is, the teacher has the opportunity to select the appropriate pedagogical means with the help of which the successful development of the student is possible and, according to Kegan (1982), the transition of the student from one stage to another, higher. As a result, internal motivation is formed, which is necessary for successful learning activities.

Thus, we believe that the teacher's personality is the fundamental factor influencing students' motivation.

Knowledge of a foreign language is the key to the culture of other people speaking that language (Tamimi \& Seyyed, 
2017; Zelenska, 2019; Cui, 2020; Zhuo et al., 2021). Language is a means of communication and expression of thought and the accumulation of cultural values. The language reflects the experience of the people, its history, material and spiritual culture. Obtaining in the learning process knowledge about the culture of the native country and the country of the studied language (about literature, music, architecture, painting, history, traditions, etc.), about social phenomena, about cultural activities, the student compares the knowledge gained and forms his attitude to him, your beliefs. Any educational material is easier to assimilate if it is emotionally coloured and causes positive emotions in students. In a friendly, creative atmosphere in the classroom, communication barriers are removed, and it is stimulated as a stable, highly developed desire for communication, for personal contact with people, expressed in the ease of entering into social contact. The most effective in implementing these goals are exercises-dialogues, discussions, dramatization, collective research search, role-playing games, project activities.

A teacher's activity is impossible without relying on cognitive motivation (motivation for novelty), motivation for achievement through the development of a success motive. Deprived of the latter, the student's learning activity loses its positive and emotional colouring. To increase the level of motivation is necessary to mobilize cognitive capabilities, mental processes of the individual, stimulate activity and perseverance in achieving results, the ability to substantiate and defend one's point of view. The use of a multimedia integrated block, which includes works of fine art, architecture, poetry and prose of prominent foreign authors, made it possible to supplement nature with aesthetic expressiveness of visual forms, activated the students' abilities, and expanded the scope of applied pedagogical efforts.

At present, the goals of studying a foreign language should not be taught as such. The content will be only pragmatic knowledge, skills and abilities, but the individual's education. In this case, the content is culture, which is understood as the spiritual values personally mastered in the activity, the space in which the process of personality socialization takes place. This reorientation of education in acquiring a foreign language from "knowledge of the centric to culture-consistent" will make a person educated and cultured, teach not thoughts, but think, not ready-made knowledge their application, but creativity.

Thus, we believe that involvement in the culture of the people is also an essential factor influencing the motivation of students.

Imagine the interconnection of increasing the motivation of students to learn two foreign languages through the personality of the teacher and the involvement of students in the culture of other people (Figure 2).

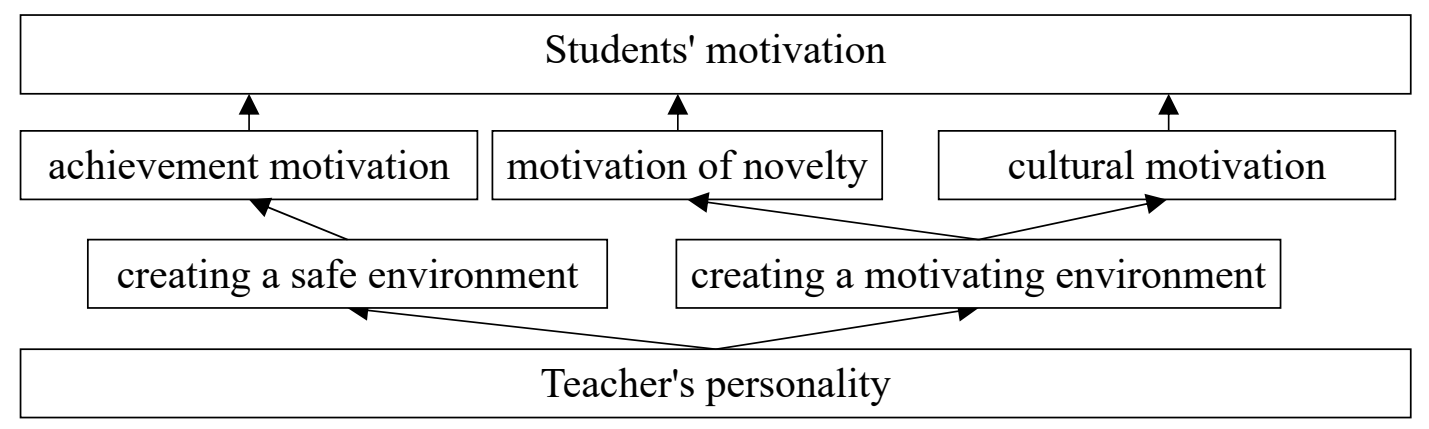

Figure 2. The Interconnection of Increasing The motivation of Students to Learn Two Foreign Languages Through the Personality of the Teacher and the Involvement of Students in the Culture of Other People

Source: developed by the authors

\section{Methods}

The authors conducted research in their universities, consisting of two stages:

Stage 1 - identifying the reasons for unwillingness to learn a second foreign language; their analysis and development of measures to reduce their negative impact. Stage participants: State Institution "South Ukrainian National Pedagogical University named K. D. Ushinsky", Bohdan Khmelnytsky Cherkasy National University and West Ukrainian National University. Dates: 2019 (2 semester) and 2020 (1 semester). The number of respondents is 224 people. 
Stage 2 - implementing the proposed methodology for increasing students' motivation to learn two foreign languages. Stage participants: State Institution "South Ukrainian National Pedagogical University named K. D. Ushinsky", Municipal Institution of Higher Education "Khortytsia National Educational Rehabilitation Academy" of Zaporizhzhia Regional Council. Dates: 2020 (2nd semester) and 2021 (1 semester). The number of respondents 116 people. The respondents were divided into three groups:

Group 1 - the second foreign language was included in the "Compulsory disciplines" block.

Group 2 - the second foreign language was included in the "Selective disciplines" block.

Group 3 - the second foreign language was included in the block "Selective disciplines" + the teacher presented himself and his discipline with reference to the culture of the people.

Each group was divided into two groups (A - formal education; B - education according to the proposed method, i.e., emphasizing the connection of languages and involvement in other people's culture). All groups were assessed according to the following criteria:

1. desire to come to class

2. interest in getting to know the culture better

3. desire to read books in the original language

4. desire to watch films in the original language

5. desire to listen to music in the original language

6. desire to visit the country

7. desire to move to work in the country

8. homework assignments

\section{Results}

The results of the first stage of the research are the study of the reasons for the reluctance to learn a second foreign language (Figure 3).

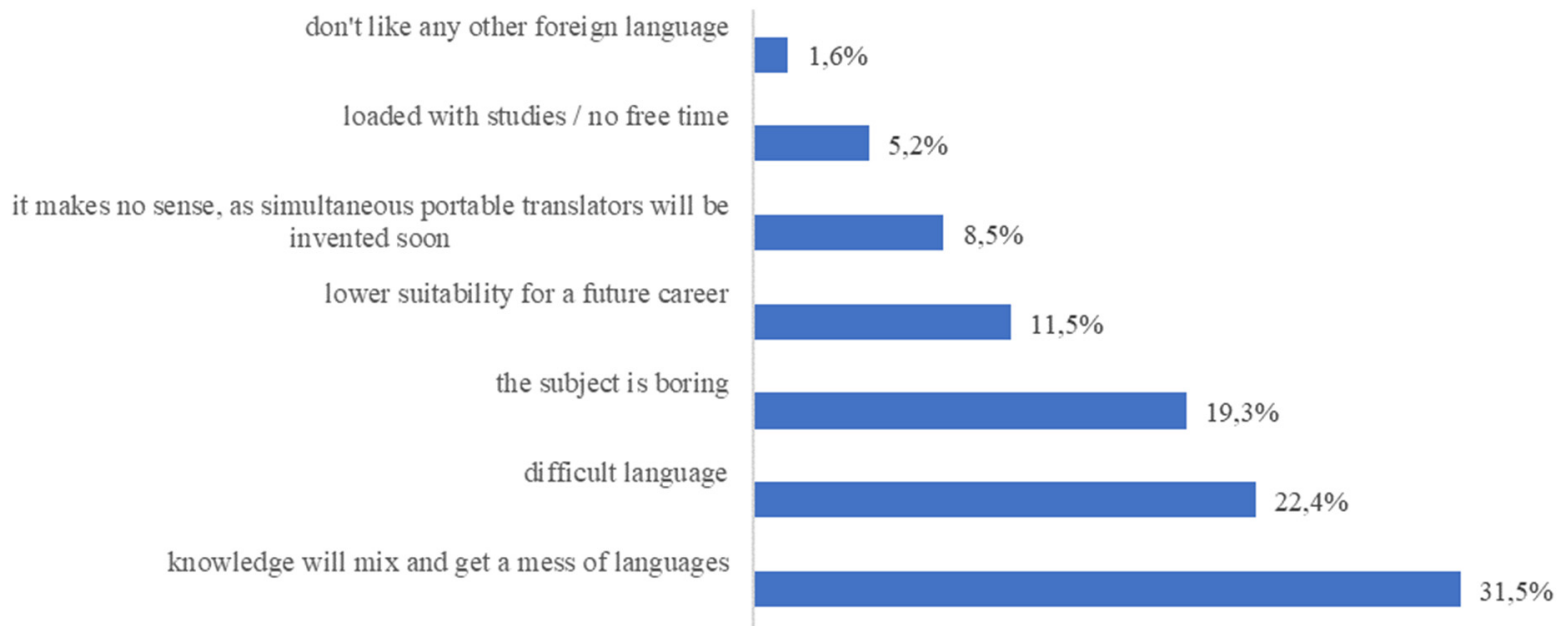

Figure 3. The Main Reasons for the Reluctance of Students to Simultaneously Study the Two Main Languages Source: developed by the authors

Using survey data and research problem field, we believe that it is necessary to add the teaching of a foreign language in the context and in connection with the first to the two main aspects identified by the scientists (the personality of the teacher and the emphasis on foreign culture (Figure 4). 


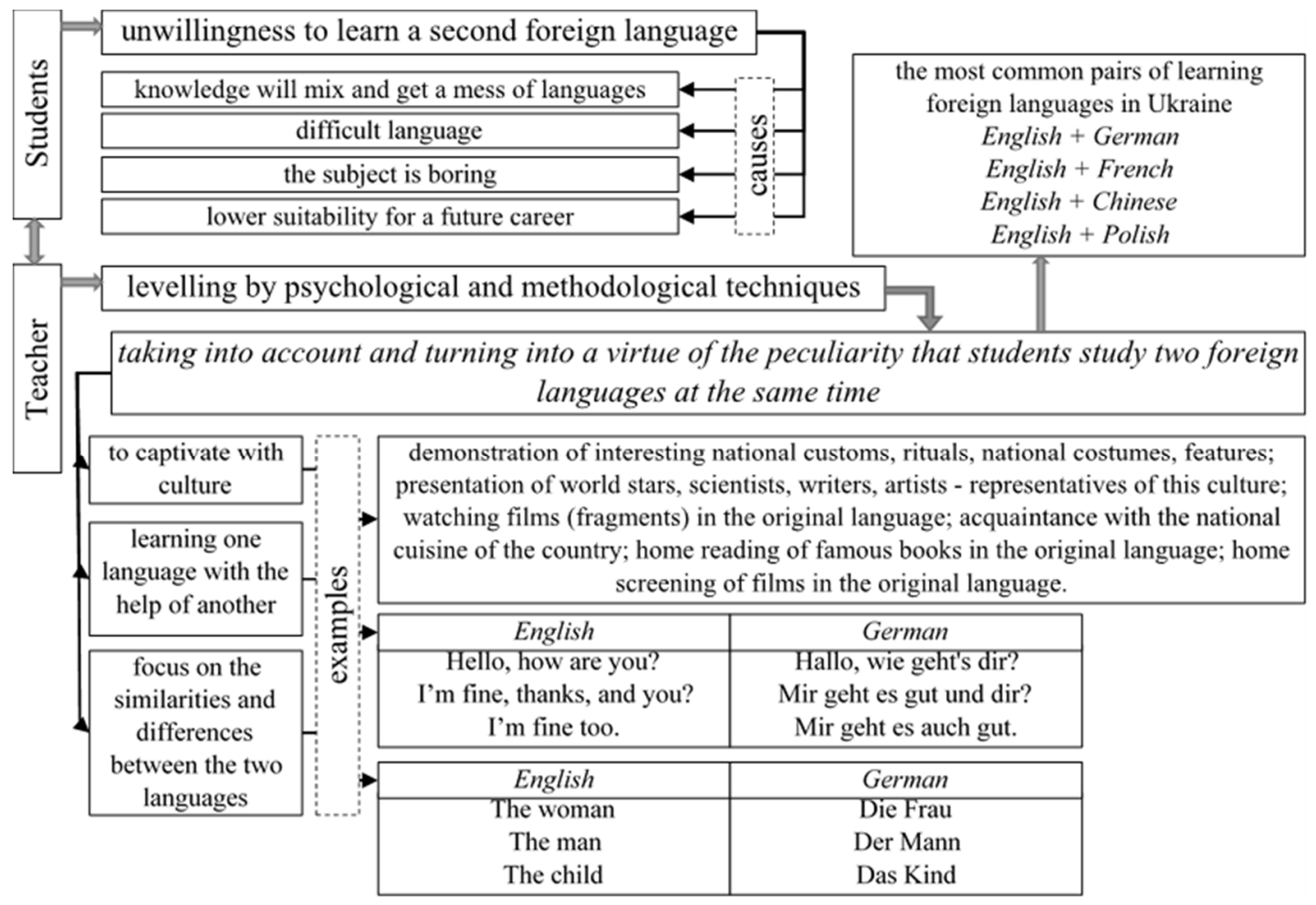

Figure 4. Psychological and Methodological Instruments Influencing the Maintenance of a Motivation to Learn Two Foreign Languages

Source: developed by the authors

Results of approbation of the method (Stage 2): the proposed method has shown its effectiveness in all three groups (Figure 5).

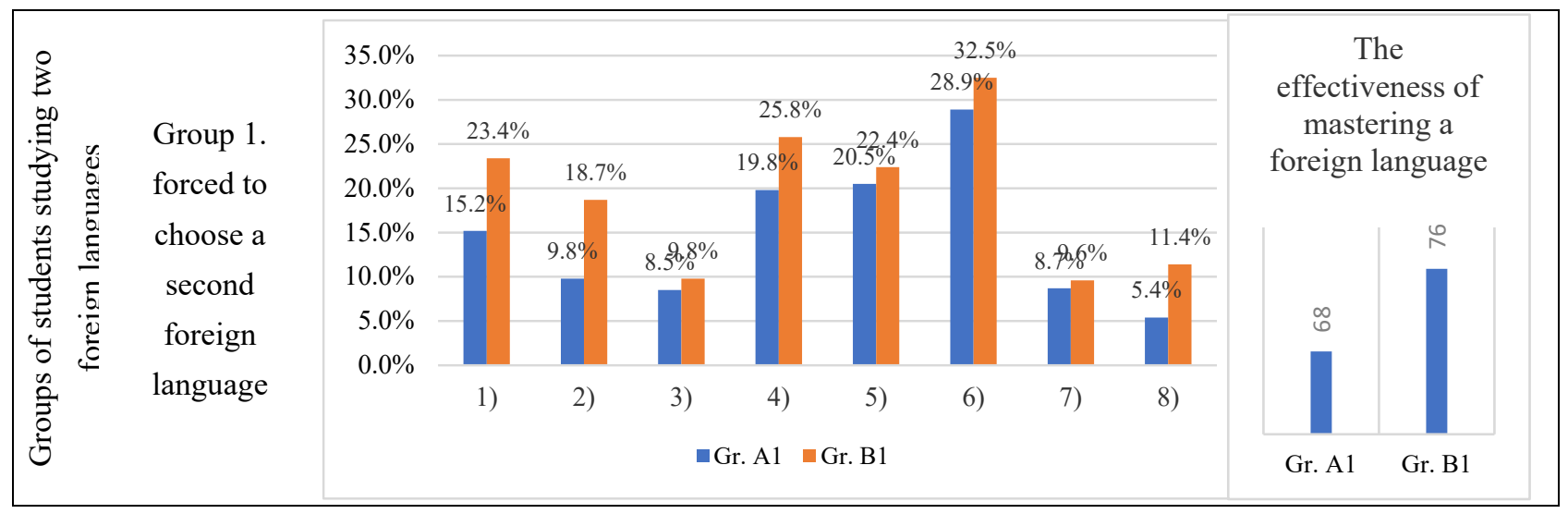




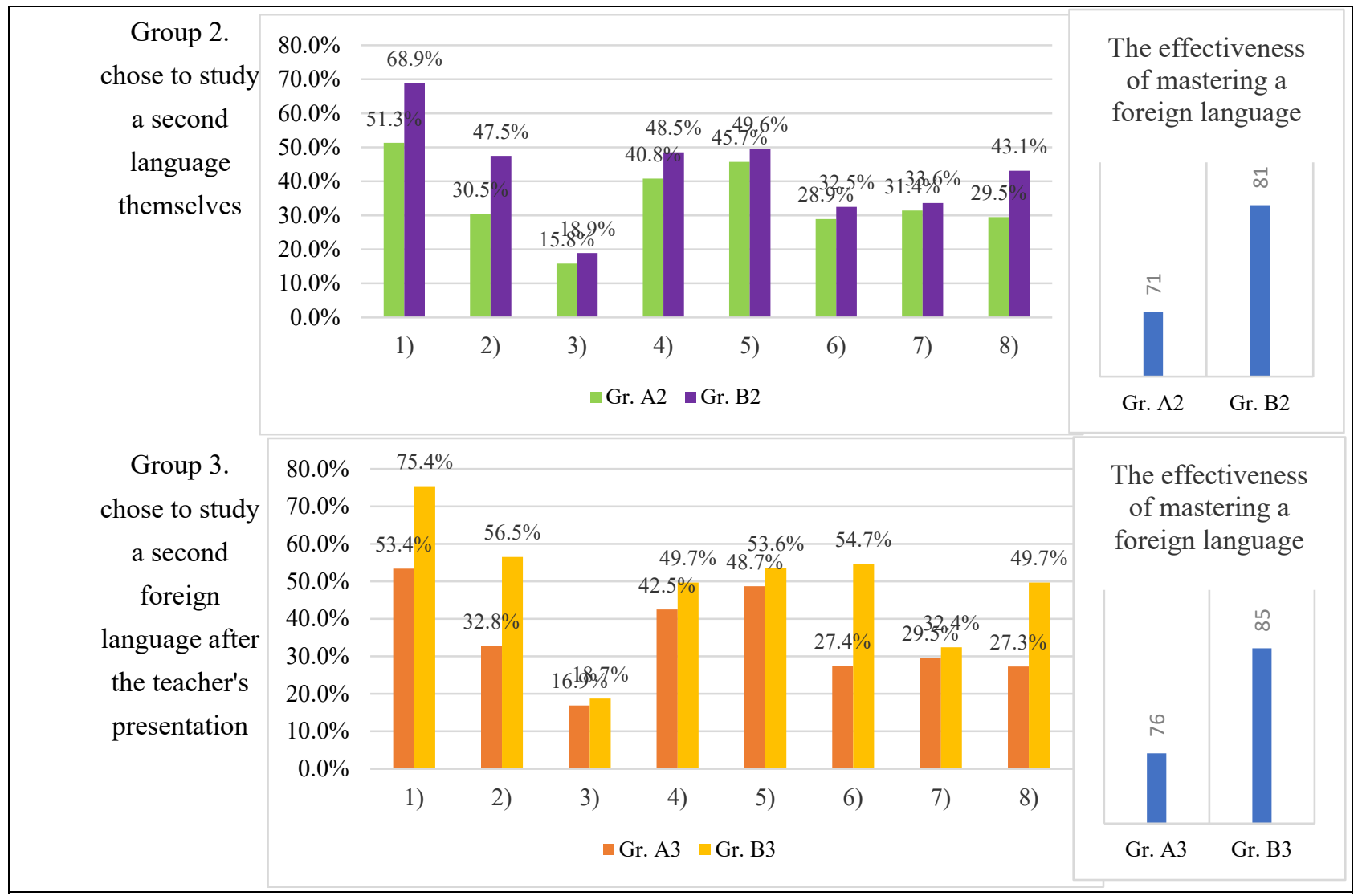

Figure 5. The Results of Testing the Proposed Methodology Can Increase Students' Motivation to Learn Two Foreign Languages

Source: developed by the authors

\section{Discussion}

It is worth noting that students' intrinsic motivation (groups 2 and 3 ) is also a significant factor; it is the basis, at least, of starting to learn a second foreign language.

The authors also assessed mastery of a second foreign language through motivation by comparing the final marks. A more detailed analysis of the influence of motivation - what exactly it affects when learning a foreign language (grammar, listening, reading, writing, speaking) and to what extent the effect is manifested - will be the further research of the authors.

The maximum effectiveness of increasing students' motivation to learn a second foreign language is the teacher's personality, creating a safe motivating environment, focusing on other people's culture and the connection between two foreign languages. The practical value of this work is a methodology that can effectively increase the motivation of students to learn a second foreign language, which is based on the synergy of 3 components: (1) the personality of the teacher, who can create (2) a safe motivating environment, focusing on the culture of other people and (3) connection between two foreign languages. This methodology, without significant adaptation, can be applied to the study of two or more foreign languages, with minor adjustments - for other disciplines.

\section{Conclusions}

The increase in motivation goes through primary interest through the disclosure of the characteristics of other nations, the involvement of students in independent work in the classroom; problematicness of tasks and situations; control of knowledge of skills and abilities; the use of cognitive games; regional material and, of course, the benevolent attitude of the students. The essential motivational incentive for learning a foreign language is the desire to expand one's broad horizons. The leading role is played by the desire to get acquainted with the country's life of the target 
language, with its geography, history, and everyday life. The attraction of cultural materials dramatically increases the motivation for learning. For us, this conclusion is significant since learning students' language without motivation is impossible.

Analysis of masterpieces, works of the country's culture of the target language, consideration of images in cultural and historical relationships is the best way to understand the culture of a native speaker, allowing students to imagine themselves as a member of a single community of world culture. In conjunction with the first, the construction of a methodology for teaching a foreign language as a second made it possible to level the main fears of students in studying two languages simultaneously. The most important thing is the teacher's personality, when he treats students with understanding, presents the culture of other people with inner interest, and understands the features of two foreign languages and the main difficulties students face when learning foreign languages.

The practical value of this work is a methodology that can effectively increase the motivation of students to learn a second foreign language, which is based on the synergy of 3 components: (1) the personality of the teacher, who can create (2) a safe motivating environment, focusing on the culture of other people and (3) connection between two foreign languages. This methodology, without significant adaptation, can be applied to the study of two or more foreign languages, with minor adjustments - for other disciplines. The unexplored aspects of the research can become the subject of further research, namely the approbation of the methodology for studying the third foreign language and the development of a similar methodology for the study of professional disciplines.

\section{References}

Bashynska, I., Garachkovska, O., Kichuk, Ya, Podashevska, T., \& Bigus O. (2021). Smart Education 4.0: Balancing Dual-Distance and Reskilling Revolution. Studies of Applied Economics, 39(6), 1-11. https://doi.org/10.25115/eea.v39i6.5262

Berehil, M. (2022). Boosting Students Motivation Through Gamified Hybrid Learning Environments Bleurabbit Case Study. In: Networking, Intelligent Systems and Security (pp. 561-576). Singapore: Springer.

Burhonova, G. (2021). Modern Methods of Teaching a Foreign Language at a Non-linguistic University. Bulletin of Science and Practice, 7(5), 475-484. https://doi.org/10.33619/2414-2948/66/52

Cui, R. (2020). Review of Research on Foreign Language Anxiety and Foreign Language Enjoyment. Scientific and Social Research, 2(3), 108-111. https://doi.org/10.36922/ssr.v2i3.1003

Garn, A. C., \& Simonton, K. L. (2022). Motivation beliefs, emotions, leisure time physical activity, and sedentary behavior in university students: A full longitudinal model of mediation. Psychology of Sport and Exercise, 58, $102077 . \quad$ Retrieved from https://www.researchgate.net/profile/Kelly-Simonton/publication/355151917_Motivation_beliefs_emotions_leis ure_time_physical_activity_and_sedentary_behavior_in_university_students_A_full_longitudinal_model_of_m ediation/links/616049bce7993f536ca6b8a4/Motivation-beliefs-emotions-leisure-time-physical-activity-and-sede ntary-behavior-in-university-students-A-full-longitudinal-model-of-mediation.pdf

Isaeva, A., Semenova, G., Nesterova, Ya., \& Gudkova O. (2021). Augmented reality technology in the foreign language classroom in a non-linguistic university. E3S Web of Conferences 273(4), 12119. https://doi.org/10.1051/e3sconf/202127312119

Isroilova, B. (2021). The role of motivation in learning foreign language. European Science Review, 3-4, 30-33. https://doi.org/10.29013/ESR-21-3.4-30-33

Kegan, R. (1982). The Evolving Self: Problem and process in human development. Cambridge, MA: Harvard University Press.

Kozlovska, G., Furman, A., Kolesnichenko, N., Kharchenko, N., Halatsyn, K., \& Matorina, N. (2021). Psychological research of the ability to foreign languages acquisition. Estudios de Economia Aplicada, 39(5).

Maslow, A. (1943). A Theory of Human Motivation. Psychological Review, 50(4), 370-396.

Merlin, V. (1971). Lectures on the psychology of human motives. Perm: PGPI.

Muradov, U, Kadirova, N., Ikramova, R., \& Kuchkeldiyeva, U. (2020). The Role of Motivation in Learning Foreign Language. The American Journal of Social Science and Education Innovations, 2(12), 14-21. https://doi.org/10.37547/tajssei/Volume02Issue12-04

Pavlyuk, E. S. (2019). Professional Context of Teaching Foreign Languages in Non-Language Universities. 
Education and Science without Limits Fundamental and Applied Researches, 10, 267-270. https://doi.org/10.36683/2500-249X-2019-10-267-270

Poplavskyi, M., Rybinska, Y., \& Ponochovna-Rysak, T. (2020). The specific of Synesthesia in contemporary American and English poetry and its impact on the reader. Cogito, 12(3), 297-315.

Pozdniakova, S. (2018). Principles of Education Content in Teaching Foreign-language Professional Communication in Non-linguistic Universities. SHS Web of Conferences, $50,01141$. https://doi.org/10.1051/shsconf/20185001141

Prokopenko, O., Holmberg, R., \& Omelyanenko, V. (2018). Information and communication technologies support for the participation of universities in innovation networks (comparative study). Innovative Marketing, 14(3), 17-29. https://doi.org/10.21511/im.14(3).2018.03

Rethinasamy, S., Paee, R., \& Ramanair, J. (2021). Malaysian Undergraduates' Beliefs and Motivation for Learning Japanese as a Foreign Language. Qualitative Inquiry, 12(6), 1519-1529.

Riyanti, D. (2020). The role of motivation in learning English as a foreign language. Journal of English Language Teaching Innovation and Materials, 1(1), 29-35. https://doi.org/10.26418/jeltim.v1i1.27788

Selivanova, O., Gromova, Ch., \& Mashkin N. (2018). Improving student motivation for learning the second foreign language. XLinguae: European Scientific Language Journal, 11(1), 218-229. https://doi.org/10.18355/XL.2018.11.01.18

Tamimi, S., \& Seyyed, H. (2017). Foreign language learning and identity reconstruction: learners' understanding of the intersections of the self, the other and power. CEPS Journal, 7(4), 13-36. https://doi.org/10.25656/01:15209

Telyani, A. E., Farmanesh, P., \& Zargar, P. (2021). The Impact of COVID-19 Instigated Changes on Loneliness of Teachers and Motivation-Engagement of Students: A Psychological Analysis of Education Sector. Frontiers in Psychology, 12, 765180. https://doi.org/10.3389/fpsyg.2021.765180

Tkachenko, O., Zhylenko, I., Poplavska, N., Mitchuk, O., Kuzmenko, H., \& Zolyak, V. (2021). Personnel behaviour management through social communications. Estudios de Economia Aplicada, 39(5). https://doi.org/10.25115/eea.v39i5.4837

Turski, I., Mashika, H., Tkachenko, T., Khmara, M., Komarnitskyi, I., \& Oliinyk, M. (2021). Medical tourism: Analysis of the state of international tourism and prospects for domestic development. Universal Journal of Public Health, 9(2), 27-34. https://doi.org/10.13189/UJPH.2021.090201

Urban, K., Pesout, O., Kombrza, J., \& Urban, M. (2021). Metacognitively aware university students exhibit higher creativity and motivation to learn. Thinking Skills and Creativity, 42(2), 100963. https://doi.org/10.1016/j.tsc.2021.100963

Vasiutiak, I., Babych, O., Shoptenko-Ivanova, O., Zhuravlova, A., Myroniuk, N., \& Nebesnyk, A. (2021). The Role of Sports Dance in Ensuring the Motor Activity of Students. International Journal of Human Movement and Sports Sciences, 9(6), 1299-1305. https://doi.org/10.13189/saj.2021.090625

Zelenska, O. (2019). The importance of the language and country study competence in foreign language learning of the students taking the non-linguistic master's course. Current issues of the humanities, 26(1), 143-147. https://doi.org/10.24919/2308-4863.1/26.195825

Zhuo, Ch., Ping, Zh., Yi, L, \& Yanxia, L. (2021). Interactions of trait emotional intelligence, foreign language anxiety, and foreign language enjoyment in the foreign language speaking classroom. Journal of Multilingual and Multicultural Development. https://doi.org/10.1080/01434632.2021.1890754

\section{Copyrights}

Copyright for this article is retained by the author(s), with first publication rights granted to the journal.

This is an open-access article distributed under the terms and conditions of the Creative Commons Attribution license (http://creativecommons.org/licenses/by/4.0/). 